\title{
The Leadership Competencies of Prof. Yılmaz Büyükerşen as the Chancellor of Anadolu University
}

\author{
Prof. Dr. Yılmaz Büyüikerşen'in Liderlik Yeterlilikleri \\ Anadolu Üniversitesi Rektölüğü Döneminde
}

\section{Basil Okoth}

Başvuru Tarihi: 11.01 .2017

Kabul Tarihi: 19.03.2018

\begin{abstract}
Transformational, charismatic, visionary! These are some of terms that have been popularized as the prescription for successful leadership. A leader does not have to check all the boxes to be considered successful, Prof. Yllmaz did, however. The study interviewed four participants who worked under Prof. Yllmaz as the chancellor as Anadolu university to examine their perception of Prof. Yilmaz's leadership competencies according to Dulewicz and Higgs (2006) framework. The results indicate that Prof. Yilmaz performed highly on all competencies considered and inspired a lasting mark of loyalty and commitment and admiration among his followers and peers. His ability to comprehend the emotions of his followers and his will to communicate to their feelings helped endear him to his staff. Creating a vision and formulating a strategy to reach it, then (backed with the requisite resources) being capable of communicating this vision to an empowered workforce is the total summary of Prof. Yilmaz's (and indeed any other leader's) path to leadership success.
\end{abstract}

Keywords: Emotional Intelligence; Managerial Competences and Intellectual Dimensions

\begin{abstract}
Öz
Dönüşümsel, karizmatik, vizyoner! Bunlar başarıl liderlik için sahip olunması gereken özelliklerden birkaçıdır. Bir lider başarılı olabilmesi için tüm seçenekleri kontrol etmek zorunda değildir ki bununla beraber Prof. Yilmaz Büyükerşen de bu şekilde davranmıştır. Bu çalışmada Dulewicz ve Higgs (2006)'in öne sürmüş olduğu yapıya göre Prof. Yllmaz Büyükerşen’in liderlik yetenekleri Anadolu Üniversitesi rektörüyken onun altında çalışmış olan dört katılımcının algiları incelenerek ele alınmıştır. Sonuçlar Prof. Yilmaz Büyükerşen’in ele alınan tüm yetenekler için yüksek performans gösterdiğini ve onu takip edenler ile akranları açısından sadakat, bağllik ve hayranlikta ilham verici biçimde kalıcı iz bıraktı̆̆ını göstermektedir. Takip edenlerin duygularını anlama yeteneği ve hisleriyle iletişim kurma isteği onu çalışanlarına karşı sevdirmiştir. Vizyon yaratarak buna ulaşmak için bir strateji oluşturma ve (gerekli kaynakların yardımıyla) yetkilendirilmiş işgücüne yönelik bu vizyonla ilişki kurabilme becerisi Prof. Yılmaz Büyükerşen’in (ve diğer liderlerin) liderlik başarısına götüren sürecin bir özetidir.
\end{abstract}

Anahtar Kelimeler: Duygusal Zekâ, Yönetsel Yetkinlikleri ve Düşünsel Boyutları

Basil Okoth, Anadolu University Gradute School of Socal Sciences Student, basils.okoth@gmail.com 


\section{Introduction}

Between 1982 and 1992, Prof. Yllmaz Büyükerşen was the chancellor of Anadolu university, a responsibility and he handled with measurable success. He actually won the votes to proceed for a third term, but this run was halted by the new regulation from Higher Educations board prohibiting more than two terms at the helm of institutions of higher learning. He went on, in 1999 to become the Mayor of the province of Eskişehir a position he has held with great success to date. After the decision was made to found an open university, Anadolu university was the first in 1981 to open an open and distance learning faculty in 1981, and Prof. Yllmaz was at the core of this pioneer movement which culminated, in the same year, to a collaboration with TRT channel for radio classes.

The period of Prof. Yllmaz's chancellorship was a transformational period when technology was just seeping into education, institutes of higher learning needed to adapt to the changing environments, and Turkey, as a country, was becoming more liberalized as a participant in the global arena. There was need for the education standards to match and to be able to favorably compete in the world market. This means the university leadership needed to be oriented towards beneficial internal and external networking while remaining both diplomatic and assertive in its influence. This was the time for visionary leadership!

To provide more instructors to the center which was seeing an increase in the number of admissions, he founded the Faculty of Special Education in the 1983/1984 academic year, churning out Turkish first graduate instructors for the hearing impaired in 1987.

There is a general agreement in literature on leadership about the absence of a single best trait, and as Fielder's (1985) contingency theory puts it, different circumstances put different demands on the leader and his ability to adapt to the contingencies.

The main objective of this study is to investigate the leadership skills and competencies associated with Prof. Yilmaz during his tenure at the apex of the university, and which spurred his success at the time. I seek to examine his leadership competencies (intellectual, managerial and emotional) within the confines of contingency theory and using the framework provided by Dulewicz and Higgs (2006), which com- bines traits and profiles of the leader with contingent factors as well as the degree of follower commitment and loyalty created by the leader. I also try to find out how his actions impacted the emotions and attitudes of the university staff. This study seeks to put to practice the classification of leadership traits within the dimensions of Dulewicz and Higgs (2006).

\section{Literature Review}

\section{Leadership}

Studies have tried to comprehend leadership within different constructs often leading to varied results. The search for qualities that make successful leadership has been the subject of many studies since the beginning of organized society but is still poorly understood' (Shields, 2003; p. 5). Some of these studies have used the historical figures like Napoleon, Mahatma Gandhi and Martin Luther among others to try to put down the characteristics that would suit a great leader, yet the concept itself still carries different meanings to different people. Kets de Vries (1997) for instance outlines vision, charisma, empowerment and the ability to get people involved as the makings of a good leader; Astin and Astin (2000) talk about movement towards change- not just any change, but to a value-based change. They associate effective leadership with characteristics of emotional intelligence; managerial competences and intellectual dimensions.

This study adopted the perception of leadership given by Richardson in the foreword of Astin and Astin (2000) as a cultural construct that reflects the values and norms of their respective societies, which means that the definition of leadership changes with the changes in social circumstances and is different for every society and individual. In my qualitative semistructured interviews, I started by asking the participants about their perception of leadership especially with respect to an academic institution.

The one thing that most people seem to agree on, is the exceptionality of Prof. Yllmaz, and this study is biased on this foundation.

As mentioned in the above section, there is no one best fix for leadership. Every situational and decision tasks a leader differently. A good leader is one who is able to identify the needs of the different settings 
and dress in the appropriate attire to handle the situations. So, is it possible for a leader to display both transformational as well transactional qualities (Bass 1998, Avolio, 1999)? As a matter of fact, they agree that a leader's possession of both qualities leads to improved commitment by their followers.

\section{Intellectual Dimensions}

The intellectual dimension of leadership deals with the cognitive intelligence and rationality in synthesizing information, comprehending the prevailing circumstance and creating effective solutions for superior performance. A study by Wepner et al (2003) that interviewed 4 deans of education revealed a preference for intellectual dimension as the basis of engaging the other competencies in problem-solving. Intelligence and cognition are mostly measured in terms of problem-solving. Problem-solving entails making decisions where the consequence is uncertain, and traditional approaches have become incommensurate. The role of a leader in this situation (according to Prinsloo and Barrett, 2013 ${ }^{1}$ ) is eliminating the obstacles that hinder the achievement of goals and take the necessary risk while doing so. But to form an guided opinion with regards to solving any problem, a leader must be able to accumulate, conceptualize and interpret copious amounts of information. Consequently, the measure of a leader's intellectual competence has been used to envisage success. Pagon et al. (2008) credited intellectually competent leaders with the ability to understand the needs, goals, demands and problems of their systems and capacity to innovate in order to catch up with the changing environment. And as Dulewicz and Higgs (2006) theorized, Pagon et al. also express support for a vision that meets the goals of the organization. Dulewicz and Higgs (2006) include critical analysis and judgment, and strategic perspective and the other factors that complete the measure of cognitive intelligence of a leader. Kirkpatrick and Locke (1991) concludes that followers respond positively to the cognitive abilities of a leader. An intelligent leader is regarded as being more capable hence deserving of respect.

\section{Managerial Competences}

The definition of the concept of competency is pegged on personal traits and behavior that results in

1 Cognition: Theory, Measurement, Implications. http://integralleadershipreview.com/9270-cognition-theory-measurementimplications/ superior outcome (Boyatzis, 1982; Cheng, Dainty and Moore, 2003; Young and Dulewicz, 2009). Identifying changes and challenges in the organizational environment and making planning for and committing resources to overcome those challenges; converting vision and long-term plans into actionable plans, and taking acceptable risks to steer the organization to success are some areas of competencies that are required of accomplished leaders. Wren and Dulewicz (2005) identified resource management, engaging communication and the ability to empower followers as the main dimensions of management competencies, and they found these to greatly contribute towards leading successful change. Geoghegan and Dulewicz (2008, p. 64) likewise found managerial competencies associated 'managing resources, empowering, developing, and motivation' to be linked to problemsolving hence success of the project. Ahmed and Mohamad (2014) stress on the significance of managerial competence to the success of a project but are keen to point out that these competencies are not similar in all managers but differ with the personal characteristics of the managers. Young and Dulewicz, (2009) also found that competencies play a role in separating performers from below-average rated leaders.

\section{Emotional Intelligence}

The concept of Emotional Intelligence (EI hereafter) has been widely covered in research (Mayer and Salovey, 1997; Goleman, 2000; Palmer et al, 2001) and has elicited varied perceptions in its definition and relevance to the leadership process. The definition proffered by Mayer and Salovey (1997) is one that treats the words that make up the concept (emotion and intelligence) separately to derive a joint meaning. Hence EI could be defined as the ability to perceive, understand and express emotions (one's own and others') in such a way that advances intellectual growth. Boyatzis et al. (2001, p. 3) "Emotional intelligence is observed when a person demonstrates the competencies that constitute self-awareness, self-management, social awareness and social skills at appropriate times and ways in sufficient frequency to be effective in the situation."

'Leadership is an emotion-laden process and emotional intelligence leads to effective leadership' (Miao, Humphrey, and Qian, 2016, p. 21). This sentiment is based on their findings that emotionally intelligent leadership creates room for employee satisfaction, 
which is then tied to improved performance and profitability. However, Walter, Cole, and Humphrey (2011) find in their review of literature a series of studies on either side of the debate. They cite the example of Goleman (1995, p. 93) who sees EI as "the sine qua non of leadership", vis a vis Locke (2005) who invalidates the use of the concept in leadership on the account of its broad definition and that it is not a form of intelligence. Water et al (2011) conclude, from their review, that EI has potential in shaping leadership, as a leader who understands the emotions of his followers is able to easily comprehend their problems and is in a position to influence their actions by appealing to their emotions. Similarly, Kerr et al (2006) found that employees perceive more emotionally intelligent leaders as more effective and go further to voice their support for the inclusion of EI as one of the recruitment and selection requirement for a manager. Mayer et al (2000) found that a high-level EI leader is more adept at monitoring feelings of his subordinates and is able to take the requisite actions. Such a leader commands loyalty among his followers, and as Cherkowski (2012, p. 65) reports, there is an improved level of commitment by teachers as a result of 'authentic expression' of emotions by the principal. The same authenticity is cited by Shields (2003:26) as one of the alluring traits of Martin Luther and Mahatma Gandhi that allowed them to achieve their goals and motivate their followers. Weymes (2002) takes a collective approach and argues that EI, by creating an atmosphere of shared passion among the players in the organization, helps to elicit a sense of trust which leads to loyalty and commitment as the organization members feel emotionally enabled to achieve the dream!

\section{Research Objectives}

In this study, I seek to examine the leadership competencies of Prof. Yılmaz Büyükerşen as the chancellor of Anadolu University (1982-1993). The competencies were examined from the perspective of the followers of Prof. Yllmaz and similarly used to determine the level of influence his leadership had on them. I investigate these competencies within the framework provided by Dulewicz and Higgs (2006) as has been discussed in the literature above.

\section{Methodology}

A substantial document search preceded an openended interview as part of a qualitative approach. The choice of qualitative approach was advised by what Westley and Mintzberg (1989) refer to as loss of economic resonance and reality associated with quantitative research. Jones and Brazdau (2015) indicate that qualitative research allows for the capture of unanticipated information and creating understanding and meaning, and is especially useful when the object of the study is to examine the views and perspectives of people. The objective of this study was to examine the leadership competencies applied by Prof. Yllmaz during his time as the chancellor of Anadolu university, and the degree of follower commitment and loyalty he created among his staff. Data for this study was collected using a semi-structured interview with academic staff who were already engaged at the university when Prof. Yilmaz was the chancellor.

\section{Sampling and Data Collection}

The sampling for this study was based on a purposeful sample where the researcher purposefully sought participants who promised in-depth understanding of the subject (Klenke, 2008), and it was done on the basis of availability of the respondents. Participants were pursued who were faculty members when Prof. Yllmaz was the rector at Anadolu university and who at some point worked closer to him than others. To achieve this, the initial participant was recruiting on the suggestion of a colleague from which snowball sampling was used (Bieranacki and Waldorf, 1981). Out of the nine participants to whom invitations were sent only four academic personnel were interviewed due to the time constraints of the study and the fact that it has been over 20 years since Prof. Yllmaz stepped down as the chancellor and most of his staff (followers) at the time have since retired. Also, some requests for interviews were not granted or were granted out of the time scope of the study. All the participants were in their 60s and had at some point held faculty or department leadership positions themselves giving them adequate authority to comment on the leadership styles of Prof. Yllmaz. The participants were guaranteed confidentiality and thus codes were used to identify them in the study. The table below shows the demographic data of the participants 
Table 1. Demographic Data of the Participants

\begin{tabular}{|l|l|l|l|l|}
\hline Participant Identifier & P1 & P2 & P3 & P4 \\
\hline Age & 69 & 61 & 60 & 65 \\
\hline Gender & M & F & M & M \\
\hline $\begin{array}{l}\text { Duration worked with } \\
\text { Prof. Y1lmaz }\end{array}$ & 8 & 20 & 22 & 17 \\
\hline $\begin{array}{l}\text { Position under Prof. } \\
\text { Y1lmaz }\end{array}$ & $\begin{array}{l}\text { Head of Faculty/ } \\
\text { Member of Senate }\end{array}$ & $\begin{array}{l}\text { Director of Research } \\
\text { and Application Center }\end{array}$ & $\begin{array}{l}\text { Faculty } \\
\text { Member }\end{array}$ & $\begin{array}{l}\text { Assistant } \\
\text { Dean }\end{array}$ \\
\hline Present Position & Retired & Institute Director & Assistant Dean & Faculty Head \\
\hline
\end{tabular}

The interview questions had fourteen items divided into three sections based on their understanding of the intellectual, managerial and emotional dimensions as discussed by Dulewicz and Higgs (2006). The questions which were initially drawn in English were translated to Turkish with the help of a colleague who has a good command of both languages. They were then translated from Turkish back to English by a different colleague to validate consistency in meaning. Two colleagues helped check the questions to ascertain their acceptability both in terms of language and content. The interviews were carried out in Turkish. The interview with the first participant was used to conduct a pilot study to ensure the validity of the research questions. The interview started by seeking a conceptualization of the concept of leadership as perceived by the participants, and then discussed how they felt Prof. Yilmaz's leadership would fit into their definition. The interviews were conducted at the offices of the participants and took an average of $30 \mathrm{mi}$ nutes. The interview began with an explanation of my interest in the leadership of Prof. Yilmaz despite being a foreigner in Turkey myself. This created a rapport where the participants offered more personal stories and experiences with their former boss. As suggested by McKenzie $(2007 ; 315)$ I tried to stay out of the conversation as much as possible, only indicating my following by nodding my head and let them fill most of the silence.

\section{Data Analysis}

The analysis process employed the use of manual thematic analysis as described by Braun and Clarke (2006). The interviews were the transcribed, translated (to English) by two different sources and coded at the individual level. A limited peer debriefing was used through a colleague who only had time to compare one of the transcribed materials in the original language and the final English version. The first participant was also engaged to check the transcribed work for approval. The themes created from the coding scheme included vision and imagination, strategic perspective, resource management, communication and developing and empowering, and form the basic competencies within which the responses the participants associated with Prof. Yilmaz were analyzed. Vision and imagination and strategic perspective were identified as the main themes whereas the other three were in the support category as represented in the table 2 below. Analysis carried out within the context prescribed by Jones, Torres and Arminio (2006: 128).

\section{Table 2. The Relationship between Themes identified in the Study}

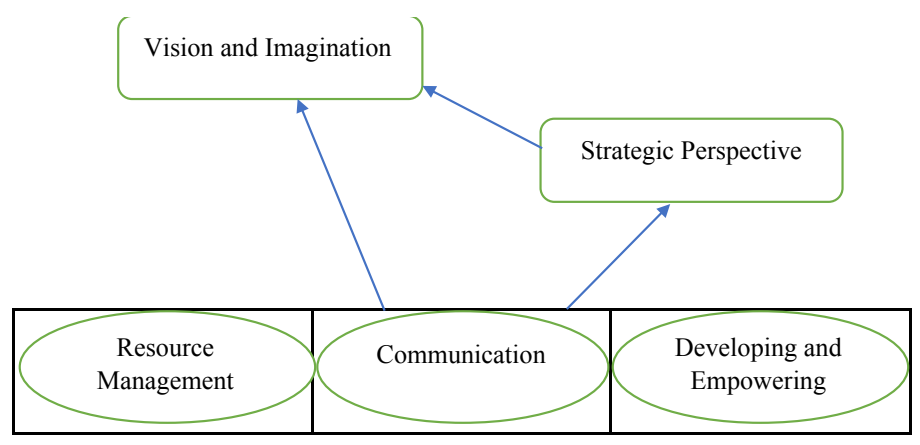




\section{Findings and Discussion}

The responses were mostly in the form of stories and narratives of events and that substantiated a particular competency. Below is the outline of the findings within the framework of the different competencies.

\section{Vision and Imagination}

Manasse (1985, p. 150) defines vision as the development, transmission, and implementation of an image of a desirable future' and Dulewicz and Higgs (2006) include innovativeness as an aspect of vision required of a leader. Prof. Yllmaz is associated with many firsts in the Turkish, the most popular being the Open and Distance Education system. Prof. Yllmaz first wrote his thoughts about the distance learning program in 1973 in a newspaper article. This was even before he became the chancellor. He adopted the Open and distance Education structure from his experience in the UK and indigenized it to fit the Turkish education system. This was the result of years of research into what could work in the local system and not just a mirror image of the English system. P2 reckons that Prof. Yllmaz didn't just bring the future to the present but ensured that it would work through analysis.

The ideas he brought into the country were not done without in-depth analysis. He was capable of seeing things from a macro perspective... he had eyes for details and a far and wide- reaching vision

He was capable of seeing the clear picture (the macro perspective of events) where everyone else never conceptualized an image. For instance, when the open education system was introduced in Turkey people had the perception that it was only to attract distant students into higher education, but he had foreseen the possibility of lifelong learning as a component. He had an eye for details and broad vision, and believed in technology as a way of completing tasks. His actions even preceded any steps by the Ministry of Education with regards.

He practically trained the first civil aviation operators in Turkey, including pilots. This resulted from the establishment of Turkey's first college of Civil Aviation with help from the International Civil Aviation Organization in 1986. He saw the need rise for practitioners in the field of aviation with the issuance of the right of operation to the private sector in 1983.
Intuition, rationality and moral imagination in determining what must be done to shape the future of an organization are part of competencies of a visionary leader Manasse (1985). Prof. Yllmaz epitomized this when he championed the established the first center for Education Research and Application for hearing impaired children at the university. While this may be attributed to a personal case, his efforts and visionary leadership led to the introduction of a center that did not only cater to the need to the hearing-impaired children, but also provided training to their families on how to communicate to them. The center also focused on early detection of hearing loss in children and became the first in Turkey to provide cochlear implants (Taşç1, 2009). This led to the establishment of the faculty of special education in 1983 to train personnel who would pursue the training of the hearing-impaired. For his level of vision P2 gave him the ultimate score:

I have never seen another visionary since Prof. Yilmaz. In Turkey I could probably only compare him to Enver Yücel (owner of Bahçeşehir university). Other than that, we have no other visionary of such caliber.

\section{Strategic Perspective}

Strategy gets the job done! One way of defining strategic leadership is as the ability to forge relationships that ensure the future viability of the organization. Ireland and Hitt (1999, p. 43) define it as "a person's ability to anticipate, envision, maintain flexibility, think strategically, and work with others to initiate changes that will create a viable future..." The value of experienced opinion in influencing changes was never lost on Prof. Yllmaz. He would analyze an issue and determine the required inputs and then look for experts in the fields. If he could not get the kind of skills and support he needed with the university or in the country, then he went out of the country for it. Knowing the value of strategic partners and other stakeholders is considered a key competency of a leader. Prof. Yilmaz managed to get into agreements with many local and foreign organizations in order to advance the cause of Anadolu. NASA, Pennsylvania State University and British Open Education system are among the outfits he dealt with in the international scene. In order to advance the young school of civil aviation, he championed partnership with various French educational institutions like École nationale 
supérieure de l'aéronautique et de l'espace (SUPAE$\mathrm{RO})$, École nationale de l'aviation civile (ENAC) and École nationale supérieure d'ingénieurs de constructions aéronautiques (ENSICA). P1 who was a member of the university senate at the time gives insights into his drive to drive progress through alliances with other organizations.

He set the field for the agreement between NASA and our institute for space studies. The notice of the expiry of his term as chancellor came while he was in Belgium negotiating a deal for 900 IBM computers to be brought to Anadolu university

But the nature of his relationships did not just end there, Prof. Yilmaz recognized the role of students in helping run things and always had an ear for them. He held prayers with them and held talks on the current state of the institution and planned events as often as he could.

Government is identified in literature as one of the limitations of strategic leadership. Despite his immense opposition to bureaucracy, Prof. Yilmaz appreciated its role in the government and forged a satisfying professional relationship with the bureaucracy in Ankara in the performance of his duties. P4 also observed the nature relationship that Prof. Yllmaz created with the government of the day.

The system supported him, and he knew how to interact with the system. Even at the height of political upheavals, he ensured that our university was not interfered with like others.

P3 however observed that the government's support and cooperation was the result of his work because not everybody got the same support.

His initiatives made him a darling of the people. He founded the hearing-impaired center. Did the nursery, primary and university. He founded the first civil aviation school. The government had no option but support him.

Even at the height of political upheavals and intolerance following the 1980 coup (infamously referred to as the 12 Eylül), he ensured that the university was cushioned from interferences, unlike many others. He always sought ways to soften the tough laws for
Ankara so that they could not bring conflicts in the university. A good example was the issue of the headscarves. When other universities were adamant in denying entry to students to their premises on their headwear owing to a government directive, Prof. Yllmaz was looking for ways to make the designs that were acceptable and less controversial in the university. Another scenario was described by participant P3

...like an event occurred during this tenure where the government at the time was rounding up individuals who were perceived to be leftists. There was one popular faculty member who was a known leftist. Prof Yilmaz intervened so that he could not be arrested even though they subscribed to different ideologies. I did not witness this event because I was not here at the time, but it became a legend for describing his gallantry and leadership...

\section{Communication}

The goals, strategy and the vision of the organization need to be communication to the employees who will help in the implementation. According to Gray (1973), the ability of a leader to direct his followers to achieving goals relies on his ability to empathize with the followers and perspicaciously communicate his intentions in a way that facilitates a supportive environment. He says that evaluative or critical forms of communication drive the staff into a defensive order and the objectives are not likely to be achieved. To achieve inspire this support, a leader needs to set himself apart as an accomplished communicator who whose message is informational and content-oriented as well as relational (Penley and Hawkins, 1985). Coming from a journalist background, Prof. Yllmaz was an exceptional communicator who knew his market exceptionally.

He gave much weight to informal communication and could easily communicate with everyone. He knew most his staff by name and their families, and knew their capabilities at work. He assigned tasks based on this knowledge.

He was friendly and intimate and quite brotherly to some and fatherly to others, and when he was offended he always took the fatherly approach, as P2 observed; 
"... with a tweak on the cheek here and a pat on the back there he made people feel valued and respected. He ensured everybody was comfortable with him from the kitchen staff to members of government protocol."

Gray (1973) however reiterates that just like authoritative communication, informal communication without certain measures may lead to deterioration of levels of respect that exists between the leader and his followers.

\section{Resource Management}

Establishing goals and providing resources necessary (both material and personnel) to achieve those goals is a vital part of achieving any form of success. Without sufficient resources, the goals are just an illusion of what could be done. Availing these resources is moot if the overseeing of their application in their areas of demand is not accomplished. The nature of resources needed in a university includes both physical and human infrastructure as well as facilities and materials that support operations. Prof. Yllmaz's tenure saw the introduction of more faculties than most universities in Turkey at the time. In his pursuit to avail these resources, Prof. Yllmaz recognized and incorporated the latest in terms of world technology. According to P3 the goal was to produce students who would lead the Turkish economic revolution:

"...there was no question about the quality of equipment we used. He obtained the latest equipment just to ensure goals were achieved. If it would do the trick, then that is what he got. He always advised the staff to present the students only with the technology they would meet in the fields or better. As a result, my students, for instance, saw, for the first time, some of the photography and videography equipment here before anywhere in Turkey".

Just as important to success is the ability to evaluate the performance of the resources employed and the staff, and Prof. Yilmaz never waited for the results to come but rather closely followed the work done by his staff. He always exerted pressure on them to achieve results, and as the participants indicate, the amount of pressure he exerted on the staff could be attributed to the many success stories the university registered.

\section{Developing and Empowering}

'Employee development is vital in maintaining and developing the capabilities of both individual employees and the organization as a whole' (Lee and Bruvold, 2003, p. 981). It shows the values placed upon the employees and assures them of their role in the future development in the organization. Prof. Yllmaz expressed his competence and ability to understand the predicament of his staff when he opened a separate department for faculty members to improve their language skills. He also facilitated the travel of some staff overseas for their masters and doctorate level studies. K2 was one of the beneficiaries of his employee development endeavors.

... I came here without a masters' degree, but through his encouragement I managed to develop. He would value everyone and seek appropriate development avenues. The current chancellor and all his deputies for instance all benefited from the English trainings that he instituted to help staff to develop their language skills.

Employee empowerment is associated with employee job satisfaction and commitment (Morrison et al., 1997; Lee and Bruvold, 2003). Burke (1988) pegs his measure of leadership on the ability to empower others. He outlines the empowering process as including provision of direction, stimulating, rewarding and developing followers. P4, another beneficiary of the development programs is still appreciative.

He rewarded hard workers and gave more opportunities to those who performed well in their tasks... Personally, I got many opportunities for training and assignments on projects inside and outside the country...

Schwartz and Ogilvy (1979) paints a picture of a change from a hierarchical to a heterarchical arrangement where the leader does not have to be right always, or does not have to take the driver's seat in all events, sometimes he may have to subordinate his knowledge to others with the required expertise. $\mathrm{He}$ thus develops his subordinates by inspiring and developing them and trusting them to be able to perform certain tasks. Prof. Yilmaz trusted the expert and experienced staff to perform tasks where his knowledge was insufficient. He once bought a satellite for about a 
million dollars based on the suggestion made to him over the phone from Europe by a member of his staff whose judgment he trusted. There was no such equipment in Turkey at the time and his knowledge was thus limited.

... he trusted my experience. He knew who to seek advice from when it came to it.

Isaacson (2012, p. 4) cites 'taking responsibility to the end' as one of the keys to Steve Jobs' success, and the same may be said of Prof. Yilmaz, except, as opposed to Jobs' desire to do everything, Prof. Yllmaz trusted his subordinates to perform tasks they were good at and assured them of his support all the way. Whenever there was a backlash as a result of the actions of an employee which he had suctioned, he would take full responsibility in the eye of the storm and as the father figure they regarded him to be, he would issue reprimands to the employee sufficient enough to deter any future transgressors. Another similarity drawn from Isaacson's description of Jobs was his disdain for focus groups and meetings. Prof. Yilmaz wanted things done when they should and no time wasted in prolonged deliberations. His decisions were definitive and quick and in case things went wrong (they rarely did for him) he took full responsibility and moved on to the next best solution.

\section{Conclusion}

An accomplished thespian, journalist and a wax sculptor, Prof. Yllmaz is still revered at Anadolu university for his exemplary leadership as his several pioneer projects. The findings described above outline the key competencies of Prof. Yilmaz as witnessed by his staff, and provides an insight into his style of leadership. Throughout the interviews, it was clear with how much esteem the staff still held Prof. Yilmaz's legacy despite the fact that over twenty years have passed since he was their boss. Within the identified themes, Prof. Yllmaz's ability to comprehend the emotions of his followers and his will to communicate to their feelings helped endear him to his staff. Creating a vision and formulating a strategy to reach it, then (backed with the requisite resources) being capable to communicate this vision to an empowered workforce is the total summary of Prof. Yllmaz's (and indeed any other leader's) path to leadership success.
With difficulty, only a couple of weaknesses could be derived from the participants' responses although not expressly indicated by them: P3 for instance indicated his hesitation to offer criticism.

I worked very close to Prof. Yilmaz for a very long time and established a relationship with him. He was in both my $\mathrm{PhD}$ and associate prof. juries. He was in charge of most of my postings and I worked close to him for around 15 years. Trying to criticize him now would amount to criticizing my own father. Are there areas of criticism for Prof. Yllmaz? There are, but as a sense of decency I am hindered. I'm blinded!

Prof. Yilmaz's expectation of nothing but the best pushed most of his staff to the edge on some occasions, as they would do everything not to cross him. People would sacrifice personal freedom and comfort to accomplish assigned tasks. Similarly, he treated excellent performance as an obligation of the staff and never much appreciated exceptionality. As much as everyone would be motivated to work to his standards, some would feel less appreciated for putting in the extra effort. It was also observed that Prof. Yllmaz never invested in leadership training and building a successive plan. One participant compared his oneman leadership style to that of the founder of the Turkish republic, Atatürk, where he observed the systems of such kind of leaders suffer because nobody can easily fill the void left by them.

Other than time constrictions, this study may have been limited by the fact that none of the participants sampled saw things differently from Prof. Yllmaz and may still be feeling indebted to his legacy.

In conclusion, the findings of these study reiterate the role played by the various leadership competencies in the motivation the employees as well as inspiring a sense of commitment and loyalty among them. These are factors that have been associated with optimal performance.

The trail of success left by Prof. Yilmaz at Anadolu university is testament to the situational approach of leadership that opposes bundling of leadership into single styles as transformational or transactional. A leader's style is influenced by the perception of the followers and the situation. Yukl (1989) combines 
various variables like subordinate effort, subordinate ability and role clarity, organization of the work, cooperation and cohesiveness, resources and support, and external coordination. The fact that Prof. Yilmaz has been able to transition from being a successful university rector to performing exceptionally as a city mayor provides support for trait theory of leadership.

\section{Reference}

Astin, A. W. and Astin, H. S. (2000) Leadership Reconsidered: Engaging Higher Education in Social Change. Higher Education. Paper 133.

Avolio, B. (1999). Full Leadership Development: Building the Vital forces in Organizations. Thousand Oaks, CA: Sage.

Bass, B. (1998). Transformational Leadership: Industrial, Military, and Educational Impact. Mahwah, NJ: Erlbaum

Bieranacki, P. and Waldorf, D. (1981). Snowball Sampling: Problems and Techniques of Chain Referral Sampling. Sociological Methods \& Social Research, 10: 141-163.

Boyatzis, R. E. (1982). The Competent Manager: A Model for Effective Performance, New York, Wiley

Boyatzis, R., Goleman, D. and Rhee, K. (2001). Clustering Competence in Emotional Intelligence: Insights from the Emotional Competency Inventory, Unpublished paper.

Braun V. and Clarke, V. (2006). Using Thematic Analysis in Psychology, Qualitative Research in Psycho$\log y, 3: 2,77-101$

Burke, W.W. (1988). Leadership and Empowerment. New York, NY: W. Warren Burke Associates, Inc.

Cheng, M.I., Dainty, A.R.J., and Moore, D.R. (2005). What Makes a Good Project Manager? Human Resource Manage J., 15(1):25- 37
Cherkowski, S. (2012). Teacher Commitment in Sustainable Learning Communities: A New "Ancient" Story of Educational Leadership. Canadian Journal of Education / Revue canadienne de léducation, 35 (1), pp. 56-68

Dulewiz, V. and Higgs, M. (2006), Assessing Leadership Styles and Organizational Context, Journal of Managerial Psychology, 20 (2), pp. 105-123

Geoghegan, L. and Dulewiz, V. (2008). Do Project Managers' Leadership Competencies Contribute to Project Success? Project Management Journal 39 (4) pp 58-67

Goleman, D. (1995). Emotional Intelligence: Why it can Matter More than IQ. New York, NY: Bantam Books.

Gray, J. W. (1973). Communication and Leadership, The National Association of Secondary School Principals, Washington, D.C

Ireland, R. D., and Hitt, O. A. (1999). Achieving and Maintaining Strategic Competitiveness in the 21st Century: The Role of Strategic Leadership, The Academy of Management Executive (1993-2005), 13 (1) Global Competitiveness, Part II, pp. 43-57

Isaacson, W. (2012). The Real Leadership Lessons of Steve Jobs, Harvard Business Review.

Jones, S. R., Torres, V., and Arminio, J. (2006). Negotiating the Complexities of Qualitative Research in Higher Education: Fundamental Elements and Issues, New York: Routledge.

Jones, V. and Brazdau, O (2015). Conscious Leadership, a Reciprocal Connected Practice. A Qualitative Study on Postsecondary Education. Social and Behavioral Sciences, 203, pp. $251-256$.

Kerr, R., Garvin, J., Heaton, N., Boyle, E. (2006). Emotional Intelligence and Leadership Effectiveness. Leadership \& Organization Development Journal, 27(4), 265-279.

Kets de Vries, M.F.R (1997). Creative Leadership: Jazzing up Business, Chief Executive, No. 121, pp. 64-66. 
Kirkpatrick, S. A. and Locke, E. A. (1991). Leadership: Do Traits Matter? Academy of Management Executive, 5(2) p. 48-60

Klenke, K. (2008). Qualitative Research in the Study of Leadership, VA, Emerald Group Publishing.

Lee, C. H., and Bruvold, N. T. (2003). Creating Value for Employees: Investment in Employee Development, Int. J. of Human Resource Management 14(6), pp 981-1000.

Locke, (2005). Why Emotional Intelligence is an Invalid Concept, Journal of Organization Behavior, 26(4), p. 425-431.

Manasse, A. L. (1985). Vision and Leadership: Paying Attention to Intention, Peabody Journal of Education, 63 (1) The Principal as Instructional Leader, pp. 150-173.

Mayer, J. D. and Saloney, P. (1997). What is Emotional Intelligence? In P. Saloney and D. J. Sluyter (Eds.) Emotional Development and Emotional Intelligence. New York. Basic Books.

Mayer, J. D., Salovey, P., \& Caruso, D. R. (2000). Emotional Intelligence as Zeitgeist, as Personality, and as Mental Ability. In R. Bar-On, \& J. D. A. Parker (Eds.), The Handbook of Emotional Intelligence: Theory, Development, Assessment, and Application at Home, School, and in the Workplace (pp. 92-119). San Francisco: Jossey-Bass.

McDonald, J. M. and Keys, J. B. (1993). Developing the Influential Manager: Experiences with Deans of Business Schools, Journal of Management Development, 12 (1) pp. 13 - 19.

Miao, C., Humphrey, R. H. and Qian, S. (2016), Leader Emotional Intelligence and Subordinate Job Satisfaction: A Meta-Analysis of Main, Mediator, and Moderator Effects. Personality and Individual Differences 102, p.13-24.

Morrison, R. S., Jones, L., and Fuller, B. (1997). The Relation Between Leadership Style and Empowerment on Job Satisfaction of Nurses, Journal of Nursing Administration, 27(5), p. 27-34.
Pagon, M., Banutai, E. and Bizjak, U. (2008). Leadership Competencies for Successful Change Management: A Preliminary Study Report, Slovenian Presidency of the EU 2008, University of Maribor, Slovenia

Palmer, B., Walls, M., Burgess, Z., and Stough, C. (2001). Emotional Intelligence and Effective Leadership. Leadership and Organization Development Journal, 22, 5-10.

Penley, L.E., and Hawkins, B. (1985). Studying Interpersonal Communication in Organizations: A Leadership Application, The Academy of Management Journal, 28 (2), p. 309-326

Schwartz, P. and J. Ogilvy (1979). The Emergent Paradigm: Changing Patterns of Thought and Belief, Analytic Report 7, Values and Lifestyle Program, Menlo Park, CA: SRI International.

Shields, M. C. (2003). Good Intentions Are Not Enough: Transformative Leadership for Communities of Difference, Lanham, Maryland. Scarecrow Press, Inc.

Walter, F., Cole, M. S., \& Humphrey, R. H. (2011). Emotional Intelligence: Sine Qua Non of Leadership or Folderol? The Academy of Management Perspectives, 25,45-59.

Wepner, S. B., Wilhite, S. C., and D'Onofrio, A. (2003). Understanding Four Dimensions of Leadership as Education Deans, Action in Teacher Education, 25:3, 13-23.

Westley, F. and Mintzberg, H. (1989). Visionary Leadership and Strategic Management, Strategic Management Journal, 10 (1) p. 17-32

Wren, J. and Dulewiz, V. (2005). Leader Competencies, Activities and Successful Change in the Royal Air Force. Journal of Change Management, 5(3) p. 295-309.

Young, M., and Dulewicz, V., (2009). A Study into Leadership and Management Competencies Predicting Superior Performance in the British Royal Navy. J. Management Development, 28(9), 794-820.

Yukl, G. A. (1989). Leadership in Organizations. Englewood Cliffs, NJ: Prentice Hall. 